\title{
Performance of Reinforced Concrete Beam with Differently Positioned Replacement Zones of Block Infill under Low Impact Loads
}

\author{
Shahrul Niza Mokhatar, ${ }^{1,}$, Mohamed Muftah Mustafa ${ }^{2}$, Salih Saed Rouwab ${ }^{2}$, and Josef \\ Hadipramana ${ }^{1}$ \\ ${ }^{1}$ Jamilus Research Centre, Universiti Tun Hussein Onn Malaysia, Parit Raja-Batu Pahat, 86400, \\ Malaysia \\ ${ }^{2}$ Faculty Civil and Environmental Engineering, Universiti Tun Hussein Onn Malaysia, Parit Raja, \\ Batu Pahat 86400, Johor, Malaysia
}

\begin{abstract}
This paper reveals a study performed on reinforced concrete with artificial aggregate concrete block infill composite beams to innovate a lightweight reinforced concrete utilizing polyethylene (PE) waste materials, such as waste plastic bags. Six beam specimens of normal reinforced concrete (NRC) and different block infill replacement zone positions RCAI $\left(\mathrm{RZ}_{1}\right)$ beams containing 100\% MAPEA with 50, 95, and $1,000 \mathrm{~mm}$ width, height, and length, respectively, were provided for the block infill, whereas RCAI $\left(\mathrm{RZ}_{2}\right)$ with different block infill positions containing a $100 \%$ MAPEA with 50,115 , and $1000 \mathrm{~mm}$ width, height, and length were provided and tested under low impact load. The steel impactor with blunt nose dropped at $0.6 \mathrm{~m}$ height which equivalent to $3.5 \mathrm{~m} / \mathrm{s}$. The behaviors of the beams were studied relative to the impact force-time and displacement-time histories, the flexural/ bending cracks, and the impact failure. Results show that the overall failure modes of all the beam specimens were successfully recorded. In addition, the residual displacements of the $R Z_{2}$ was almost same than those of the $R Z_{1}$ and the significantly lower than those of the NRC. In the reinforced concrete beams, less stressed concrete near the neutral axis can be replaced by certain light weight material like waste plastic bags as modified artificial polyethylene aggregates to serve as an artificial aggregate.
\end{abstract}

\section{Introduction}

Currently, the reduction of concrete heavy weight has been a challenge to engineers. The weight reduction is necessary because of the increasing demand for large constructions, as well as for economic and aesthetic purposes [1]. Moreover, practitioners have been challenged in producing cost-effective solutions to satisfy this demand. Furthermore, sustainability is another essential concern in the construction industry. Sustainability means

* Corresponding author: shahruln@uthm.edu.my 
satisfying the demands of the present generation without compromising the ability of the future generations to meet their needs.

This can be achieved by reducing, reusing, and recycling waste materials; it also means shifting toward green technologies and reducing Carbon dioxide $\mathrm{CO} 2$ emissions. Sustainability can also be characterized as the minimized use of resources. As a result, the development of lightweight concrete as an alternative to normal weight concrete has attracted immense interest [2]. At present, lightweight concrete has become most popular among researchers because of its special properties. Furthermore, lightweight concrete can address the weight problem in contrast to normal concrete with its approximate density at about 2,400 kg/m3 [3]. The demand for lightweight concrete in various modern construction applications has been increasing because of its advantages, including its low density that significantly replaced less stressed or unutilized concrete structures by lowcost, sustainable, and environment-friendly alternatives. This can be accomplished by replacing the aggregate in concrete with increased amounts of supplementary cementing materials, or by replacing less stressed or unutilized concrete with other low-cost and environment-friendly materials.

At the same time, Malaysian citizens generate nearly $0.8 \mathrm{~kg}$ of garbage daily, which mostly contains polyethylene (PE) materials. Urban areas are estimated to produce $1.5 \mathrm{~kg}$ garbage every day. In fact, waste plastic bags are among the major contributors to the increasing number of solid waste production in this country, in which only $1 \%$ to $3 \%$ of the solid waste materials are recycled. Plastic bags can cause certain inconveniences to society. The aggregate production of plastic waste can produce lightweight concrete characteristics by replacing normal plastic aggregates with lightweight ones. One of the solutions to this solid waste management problem is the conversion of waste plastic bags to modified artificial polyethylene aggregates (MAPEA), which can be utilized on concrete. With its high solidity, good abrasion behavior, and weak thermal conductivity, the use of MAPEA can significantly improve several properties of concrete. In addition, this aggregate has zero impact and crushing value [4]. However, Mokhatar [5] found that polyethylene can be used as an aggregate replacement for reinforced concrete beam (RCB) with artificial aggregate concrete block infill (RCAI). Similarly, the combination of the economy of reinforced block infill beams and the strength of RC beams is attempted in the block infill beams. The bond between the concrete layers and the block infill at its concrete interface are inadequate to ensure that sliding between the two layers is prevented.

In reinforced concrete beams (RCB), the strength of the concrete near the neutral axis is not completely used. The concrete above the neutral axis is less stressed, whereas the concrete below serves as a shear transmitting medium. The partially used RCB concrete can be replaced by blocks, such that, the combination of the economy of the RCB and the strength of the RC beams is attempted in the block-filled beams. The bond between the block and the concrete layers at the block concrete interface should be adequate to prevent slips between the two layers. An experiment was performed on the block-filled RCB based on the maximized stresses at the top and bottom of the beams, as well as the zero stress in the neutral axis. Thus, cheap and light materials can be used near the neutral zone for light weight and economy [6]. The behavior of block-infilled RCB under cyclic loading was investigated through experimentation, and the results were compared with the conventional RCB values. The load carrying capacity of an infilled beam was then observed to be approximately $80 \%$ of the conventional RCB [7]. The ratio between the depth of the inserted AAC blocks to the overall depth of the solid section can be a factor contributing to this result [8]. In fact, the experiment on the block-infilled RCB revealed that nearly $30 \%$ of concrete was conserved [9]. The analytical and experimental investigations on infilled frames under static and lateral loads suggested that the load-carrying capacity and stiffness of the infilled frame is greater than those of the plain frame [10]. The experiment on the 
beams with light weight brick core with Ferro cement form observed that the ultimate load of the beams increased when welded wire mesh was used in the fiber cement forms [11].

Impact loading is among the significant factors contributing to the effective use of structural materials. This is predominantly among the factors that focused on the structural elements of both steel and concrete. The impact properties of concrete have attracted interest because of the possibility of impact loading in the predicted service life of a concrete structure. Various situations have been encountered wherein structures are subjected to certain types of impact loading. These situations include various forms of missile impact, gas explosions, construction accidents, vehicle impacts, and pile driving. The impact from an object colliding with a concrete structure can be classified into hard and soft impacts, depending on the relative characteristics of the projectile (or striking object) and the target (or structure). Different forms of damage can occur during a hard impact with concrete structures. The contact zone is subjected to intense dynamic stresses, which can produce crushing, shear failure, and tensile fracturing. These stresses can result in spilling and crater formation, penetration, back-face scabbing, perforation or shear failure, and flexural failure of the target [12].

In summary, the statically loaded RC structure displays dissimilar behavior relative to impact loading structures. Thus, impact loading is among the dynamic factors that should be considered in the analysis and design of structures. The prediction on how high- and low-velocities impact load levels can affect normal RC elements was experimentally tested. The test considered the dynamic (impact) behavior of RC element as studied by Chen et al. [13], Fiquet et al. [14], Kishi et al.[15], and Giraud et al. [16], Fujikake et al. [17], and Saatci et al. [18]. However, these studies were not to fully elucidated the dynamic behavior of RCB with block-infilled. Thus, this paper aims to present the results of the impact response of reinforcement concrete beam RCB with RCAI with differently positioned replacement zones of block infill and to propose a novel lightweight reinforced concrete (RC). The block infill can be placed within of the beam cross - section near the calculated depth of the neutral axis.

\section{RCB with RCAl with different block replacement zones (BRZ)}

The replacement zone in the RC beam, where concrete near neutral axis may be replaced by block infill was obtained with the use of stress block for the limited state design of the $\mathrm{RCB}$. This block infill replacement zone is shown in Fig. 1. Block replacement zone, $\mathrm{RZ}_{1}$ can be written as:

$$
\begin{gathered}
\mathrm{RZ}_{1}=d_{\text {max }}-d_{\min 1} \\
d_{\text {min } 1}=\frac{3}{7} X_{u}+X_{b 1} \\
X_{b 1}=\frac{4}{7} X_{u} \sqrt{1-\frac{f_{b k}}{f_{c k}}} \\
d_{\max }=D-d^{\prime} \text { where }, D \text { is a total depth } \\
d^{\prime}=(2 \times \text { cover }+\varnothing \text { bar })
\end{gathered}
$$

where $d^{\prime}$ is the concrete layer thickness necessary to maintain the bond between concrete and steel. Each side of the tension reinforcement is assumed to provide a concrete thickness of not less than the cover provided to satisfy the bond requirement [19]. Block replacement zone, $\mathrm{RZ}_{2}$ can be expressed by 


$$
\begin{aligned}
\mathrm{RZ}_{2} & =d_{\max }-d_{\min 2} \\
d_{\min 2} & =\frac{3}{7} X_{u}+X_{b 2} \\
X_{b 2} & =\frac{3}{8}\left(\frac{4}{7} X_{u}\right)
\end{aligned}
$$

Where, $X_{b 1}$ and $X_{b 2}$ are distance between surface block replacement zone to compression force. While, $d_{\min 1}$ and $d_{\min 2}$ are distance between surface block replacement zone to top beams. $X_{u}$ is depth of the neutral axis

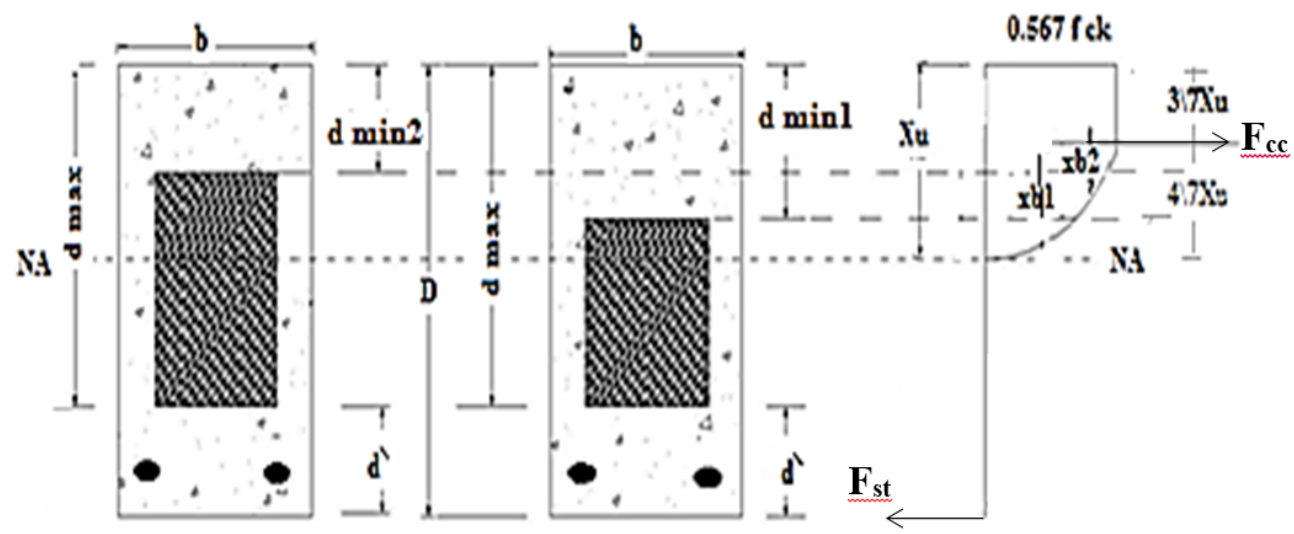

Fig. 1. Different positions of the block infill replacement zone for reinforced concrete infill beam

\section{Specimen preparation}

The, NRC, RCAI $\left(\mathrm{RZ}_{1}\right)$ and RCAI $\left(\mathrm{RZ}_{2}\right)$ designs were based on Eurocode 2. All beams possessed a rectangular cross section, 170, 250, and 1,000 $\mathrm{mm}$ in width, depth, and length, respectively. Each beam was provided with a bottom longitudinal bar. Two $12 \mathrm{~mm}$ bars were used as the bottom steel in each beam. The tensile strength obtained for each bar was $519 \mathrm{MPa}$. A $6 \mathrm{~mm}$ hot-rolled plain round rebar was used for shear reinforcement. The stirrups were vertically rectangular and open at the top. The details of the reinforcement arrangement are shown in Fig. 2. All beams were tested under low impact. The impact test was performed to compare the residual displacements and the loads between the NRC and the $\mathrm{RZ}_{1}$ and $\mathrm{RZ}_{2}$ beams. Six beams were prepared, two were used as control samples (NRC) and four were the experimental samples $\mathrm{RZ}_{1}$ and RCAI RZ $\mathrm{RZ}_{1}$ beams containing $100 \%$ MAPEA with 50, 95, and 1,000 mm width, height, and length, respectively, were provided for the block infill, whereas $\mathrm{RZ}_{2}$ with different block infill positions containing a $100 \%$ MAPEA with 50, 115, and $1000 \mathrm{~mm}$ width, height, and length were also provided, as shown in Table 1. The position of the block infill can be placed within the compression region of the beam cross-section when subjected to impact near the calculated depth of the neutral axis. 
Table 1. Sample size and volume of the beams

\begin{tabular}{|c|c|c|}
\hline Sample & Size & Volume \\
\hline $\begin{array}{c}\text { Normal Reinforced Concrete, } \\
\text { NRC }\end{array}$ & $0.25 \mathrm{~m} \times 0.17 \mathrm{~m} \times 1 \mathrm{~m}$ & $0.0425 \mathrm{~m}^{3}$ \\
\hline Beam with $\mathrm{RZ}_{1}$ & $0.05 \mathrm{~m} \times 0.095 \mathrm{~m} \times 1 \mathrm{~m}$ & $0.00475 \mathrm{~m}^{3}$ \\
\hline Beam with $\mathrm{RZ}_{2}$ & $0.05 \mathrm{~m} \times 0.115 \mathrm{~m} \times 1 \mathrm{~m}$ & $0.00575 \mathrm{~m}^{3}$ \\
\hline
\end{tabular}

*RZ $(1 \& 2)=$ Different positions of the replacement zone of the block

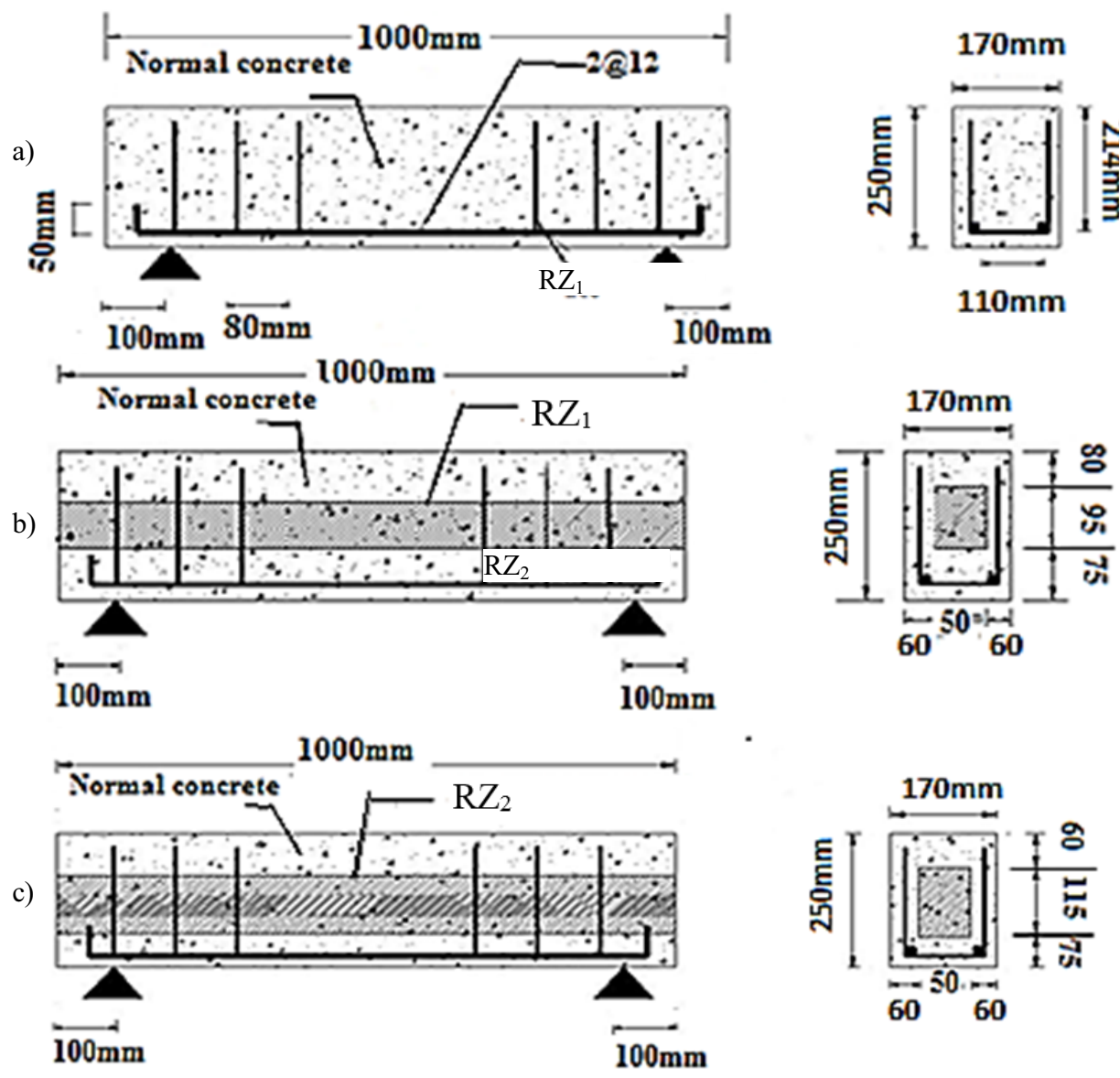

Fig. 2. Details of the a) $N R C$ b) beam with $R Z_{1}$ and c) beam with $R Z_{2}$

The beam length was $1,000 \mathrm{~mm}$, with a clear span of $800 \mathrm{~mm}$ during the preparation for testing. Tests for the $\mathrm{NRC}, \mathrm{RZ}_{1}$, and $\mathrm{RZ}_{2}$ were conducted to investigate the low impact behavior and failure mechanism of the beams. The test set-up was individually designed to test the beam specimens under impact loading. In this study, approximately $100 \mathrm{~kg}$ of dropweight is acted vertically from a height of $0.6 \mathrm{~m}$, and velocity of the load to be imposed on the specimen was approximately $3.5 \mathrm{~m} / \mathrm{s}$. During the impact tests, the steel frame structures and the support conditions should be sufficiently stiff to support the load without any significant deformation. The steel frame, a main structure for the falling weight impact tests, load cell and data logger are shown in Fig. 3. 


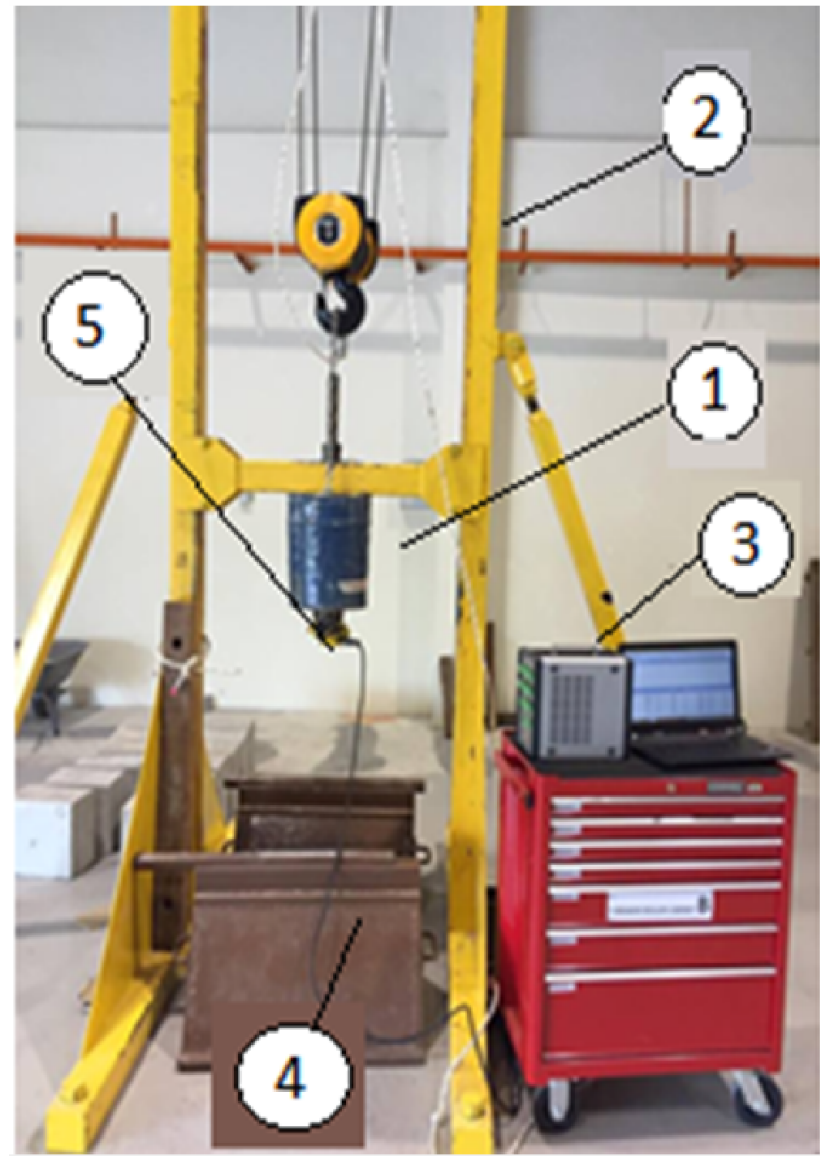

Fig. 3. Main structure of the falling weight system: 1) drop weight, 2) steel frame, 3) data logger, 4) support, and 5) load cell

\section{Experimental results and discussions}

The main purpose of the experiment is to obtain experimental results to validate the NRC investigation and to classify the ability and accuracy of the proposed $\mathrm{RCN}, \mathrm{RZ}_{1}$, and $\mathrm{RZ}_{2}$ beams by comparing them to the experimental results. In addition, this study can enrich the understanding on how reinforced concrete structures behave under various impact loads. In this study, the $100 \mathrm{~kg}$ steel weight attached to the load cell was acted vertically from a height of $0.6 \mathrm{~m}$. In the low impact loads, the overall failure modes of the specimens were successfully recorded. The typical failure modes of a specimen $\mathrm{NRC}, \mathrm{RZ}_{1}$, and $\mathrm{RZ}_{2}$ obtained from the impact loading test is shown in Fig. 4. The cracks started to vertically form at the bottom or near the impact point at this drop height. It shows that all beams failed in a bending-failure mode. However, only fine diagonal cracks which started form at the bottom propagating at an angle of approximately 45 degrees upward obtained from specimen NRC. The point at the bottom region of NRC was accomplished from the development of crack pattern and damage. This result suggested that in reinforced concrete beams, the concrete near the neutral axis can be replaced by some light weight concrete beam with RCAI to prevent the formation of a crack. 


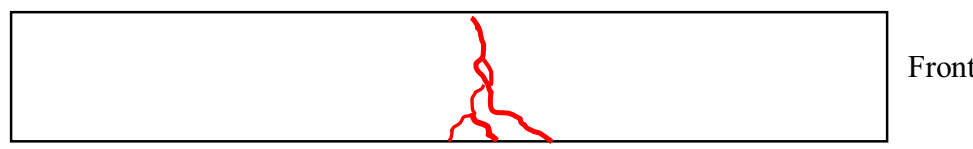

Flexural cracks

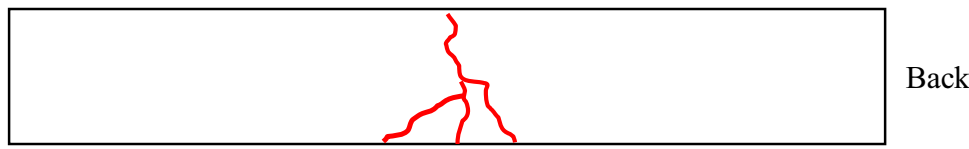

Flexural cracks

a) NRC

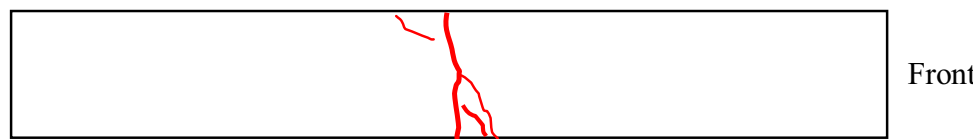

Flexural cracks

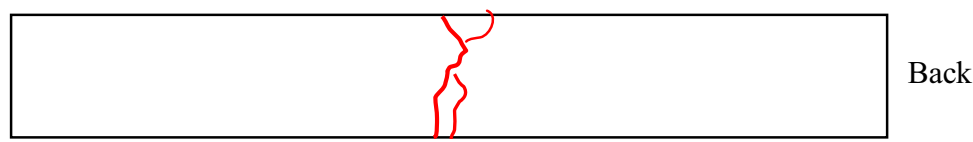

Flexural cracks

b) $\operatorname{RCAI}\left(\mathrm{RZ}_{1}\right)$

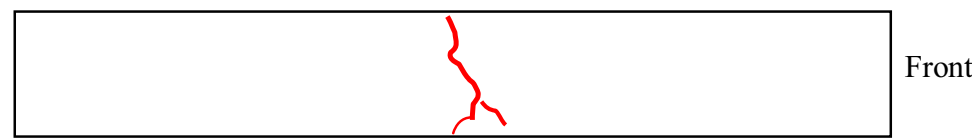

Flexural cracks

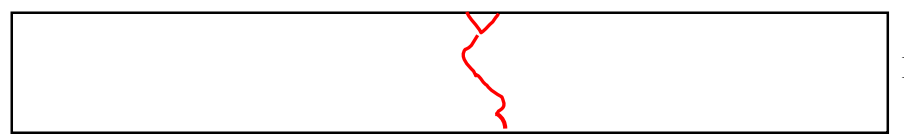

Back

Flexural cracks

c) $\operatorname{RCAI}\left(\mathrm{RZ}_{2}\right)$

Fig. 4. Crack pattern and failure of the tested beams

The average of the impact force-time and the displacement-time histories of the NRC, $\mathrm{RZ}_{1}$, and $\mathrm{RZ}_{2}$ beams are shown in Fig.5. The displacement-time histories during the $100 \mathrm{~ms}$ from the beginning of impact are also shown. Fig. 5 indicates that the minimal mid-span displacement of the $\mathrm{RZ}_{2}$ is $2.54 \mathrm{~mm}$ at $10 \mathrm{~ms}$, whereas $\mathrm{RZ}_{1}$ reported a minimal displacement of $3.10 \mathrm{~mm}$ as well. The NRC showed a considerably higher value of displacement value at $4.39 \mathrm{~mm}$ relative to the $\mathrm{RZ}_{1}$ and $\mathrm{RZ}-2$. The displacement basically depended on the stiffness of the beam. Thus, the stiffness of the $\mathrm{RZ}_{1}$ and the $\mathrm{RZ} \mathrm{Z}_{2}$ are higher than that of the NRC. From the impact force-time histories shown in Fig. 6, the maximum impact force for the $R Z_{1}$ and $R Z_{2}$ specimens were approximately 370 and $360 \mathrm{~N}$, respectively, at $10 \mathrm{~ms}$. The $\mathrm{NRC}$ has a maximum impact force at $275 \mathrm{~N}$, which is lesser than the above specimens. However, two NRC and the RCAI $\left(\mathrm{RZ}_{1}, \mathrm{RZ}_{2}\right)$ specimens behaved differently with regard to the fracture energy or energy absorption. While, the residual energy absorption of the $R Z_{2}$ was almost same than those of the $R Z_{1}$ and the significantly lower than those of the NRC. The impact loads were nearly the same but the shape of the displacement curve and the periods of the vibrations varied to a certain extent. The difference may be accounted for by the decreased energy loss and absorption of the NRC, which caused by the shorter impact event and larger deflection at failure than those of the RCAI $\left(\mathrm{RZ}_{1}, \mathrm{RZ}_{2}\right)$ specimens. Thus, increasing the number of blocks infill placed 
within the compression region of the beam cross-section when subjected to the impact load, and near the calculated depth of the neutral axis, as presented in Fig. 1, enhances the ability of the RC beam to carry loads at large deflections, thus the energy absorption of the NRC was increased.
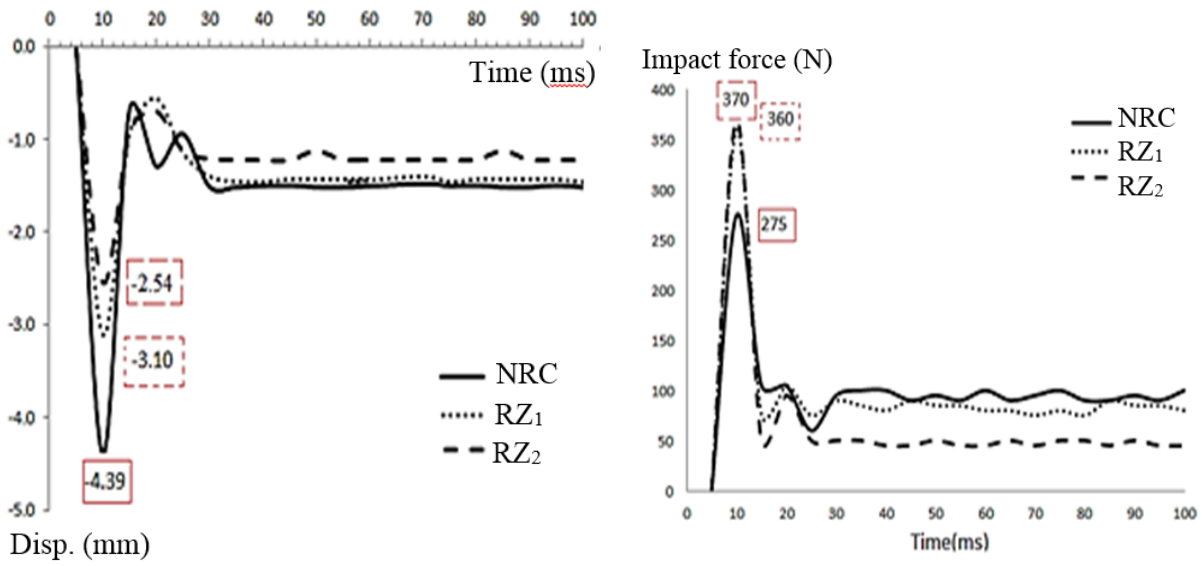

Fig. 5. Mid-span displacement-time histories

Fig. 6. Impact force-time histories

\section{Conclusion}

Experimental specimens of the low impact load tests of the NRC beams, and the development of the infill term beams RCAI $\left(\mathrm{RZ}_{1}\right.$ and $\left.\mathrm{RZ}_{2}\right)$ with modified artificial polyethylene aggregates as $100 \%$ replacement under a drop height of $0.6 \mathrm{~m}$ with impact weight was described. The position of the block replacement zone initiated in the neutral axis, and nearly half of the concrete was replaced by the block infill. The following conclusions are drawn based on the test results:

i) Under low impact loads, insignificant difference in displacement and impact force between the NRC and the $\mathrm{RZ}_{1}$ and $\mathrm{RZ} \mathrm{Z}_{2}$ block infill-filled beams were observed. Observed that the average displacement of the NRC a considerably higher value of displacement value relative to the $\mathrm{RZ}_{1}$ and $\mathrm{RZ} \mathrm{Z}_{2}$. These results showed that the proposed use of blocks infill produced desirable results under impact loads.

ii) The reduction and economy of light weight beams depended on the percentage of the modified artificial polyethylene aggregates as natural aggregates that replaced the concrete.

iii) Lightweight $\mathrm{RC}$ using waste materials as MAPEA was proposed; this necessitate further study.

The authors would like to acknowledge financial and facilities support provided by University Tun Hussein Onn Malaysia under Research Supporting Grant Scheme RSGS Code U100.

\section{References}

[1] P. W. Matthew, and D. F. H. Bennett, Economic long span concrete floors, British Cement Association, Camberley, Surry, UK, (1990) 
[2] K. Ramamurthy, E.K. Kunhanandan Nambiar, and G. Indu Siva Ranjani, Classification of studies on properties of foam concrete, Cement \& Concrete Composites, 31(6), 388-396, (2009)

[3] A.P. Adewuyi, and T. Adegoke, Exploratory study of periwinkle shells as coarse aggregates in concrete works, J. of Engineering and Applied Sciences, 3(6), 1-5, (2008)

[4] M.M. Mustafa, S.N Mokhatar, and Z.M. Jaini, Properties of different artificial lightweight aggregates and their effect on concrete strength, J. of Engineering and Applied Sciences, 11(6), 3726- 3730, (2016)

[5] S.N. Mokhatar, Z. M. Jaini, M. K. Burhanudin,M. L. A .Jeni, and M. N. N .Ismail, An experimental study of reinforced concrete beams with artificial aggregate concrete infill under impact loads, Proc. of the Int. Civil and Infrastructure Engineering Conference, Springer Singapore, 691-701, (2015)

[6] P. Govindan, and A.R. Santhakumar, Composite action of reinforced cement concrete beams with plain masonry infills, Proc. of Int. Symposium on Reinforced and Prestressed Masonry, Edinburgh, Scotland, (1984)

[7] P. Govindan, M. Lakshmipathy, and A.R. Santhakumar, Behaviour of infilled beams under cyclic loading, Indian Concrete J., 61 (5), 124-128, (1987)

[8] V.Vimonsatit, A.S. Wahyuni, and H. Nikraz, Reinforced concrete beams with lightweight concrete infill, J. of Scientific Research and Essay, 7(27), 2370-2379, (2012)

[9] U.B. Choubey, and U. Gupta. Structural response of brick-filled reinforced concrete beams, Proc. of 4th Int. Seminar on Structural Masonry for Developing Countries, Madras, India, 226-233, (1992)

[10] S. Arulselvan, K. Subramanian, P.E.B. Pillai, and A.R. Santhakumar, RC infilled frame-RC plane frame interactions for seismic resistance, J. of Applied sciences, 7(7), 942-959, (2007)

[11] H .F. Ezzat, N.A. Mohamed, B.S. Yousry, and A.A. Ahmed, Permanent ferrocement forms: A viable alternative for construction of concrete beams, The 30th Conf. on Our World in Concrete \& Structures, Singapore, (2005)

[12] R.S. Ravindrarajah, and M. C. Lyte, Energy absorbing concrete for impact loading, Proc. of the Int. Conf. on Advances in Concrete Construction, Hyderabad, India, (2008)

[13] Y.Chen, and I.M .May, Reinforced concrete members under drop-weight impacts, Proc. of the Institution of Civil Engineers-Structures and Buildings, 162(1), 45-56, (2009)

[14] G. Fiquet, and J. Dacquet, Study of the perforation of reinforced concrète slabs by rigid missiles - Experimental study Part II, Nuclear Engineering and Design, 41(1), 103-120, (1977)

[15] N. Kishi, T. Ohno, H. Mikami, and T .Ando, Effects of boundaries conditions on impact behaviors of reinforced concrete beams subjected to falling-weight impact loads, J. of Structural Engineering, 731(I-63), 299-316, (2002)

[16] R. Gueraud, A. Sokolovsky, M. Kavyrchine, and M. Astruc, Study of the perforation of reinforced concrete slabs by rigid missiles - General introduction and Experimental Study, Part I, Nuclear Engineering and Design, 41(1), 91-102, (1977)

[17] K. Fujikake, B. Li, and S. Soeun. Impact response of reinforced concrete beam and its analytical evaluation, J. of Structural Engineering, 135(8), 938 - 950, (2009)

[18] S. Saatci, and F J. Vecchio. Nonlinear finite element modeling of reinforced concrete structures under impact loads, ACI Structural J., 106(5), 717-725, (2009)

[19] R .Patel, S.K. Dubey, and K. K. Pathak, Analysis of RC brick filled composite beams using MIF, Procedia Engineering, 51, 30-34, (2013) 